\title{
SPEAKER ATTITUDE AND DEMONSTRATIVE CHOICE IN NCANE (BEBOID) ${ }^{1}$
}

\author{
Richard L. Boutwell \\ SIL Cameroon \& Leiden University
}

\begin{abstract}
Ncane is an underdocumented Bantoid language, which offers speakers multiple choices for referring to aforementioned participants. Anaphoric reference is usually made through a noun and an accompanying anaphoric demonstrative. Two anaphoric demonstratives are observed in the language and a speaker's choice of demonstrative often reflects the speaker's attitude toward the participant. This article presents examples illustrating the expression of various kinds of speaker judgments of participants through the use of anaphoric demonstratives. Accounting for such expression of attitude appears to be lacking in proposed demonstrative typologies like that of Diessel (1999). Therefore, the article concludes with a suggestion for expanding typological categories to address such subjective encoding.
\end{abstract}

Keywords: Ncane, Bantu, demonstratives, anaphora

\section{Introduction}

Ncane is a Bantoid language spoken by approximately 13,200 speakers in the North West Region of Cameroon (Simons and Fennig 2017). Previous research includes a study of the noun class system (Hombert 1980), a phonology (Richards 1991) and a preliminary sketch grammar (Boutwell 2010). This article relies primarily on text data collected by several Ncane language workers and the author between 2004 and 2015. The article provides an overview of the Ncane demonstrative system, with special attention to the anaphoric demonstratives. In addition to their function in tracking participants ${ }^{2}$ in narrative discourses, the anaphoric demonstratives are often observed to communicate negative evaluative judgments of their referents. This kind of subjective encoding appears to be similar to what Dixon (2003:91) refers to in his description of

1 This article is a revised form of a paper entitled "In reference to defective participants: Anaphoric demonstratives in the Beboid language Nchane", presented at the Colloquium on African Languages and Linguistics (CALL) in 2013. Thanks are due to the people of the Ncane speaking community, many of whom happily offered data or other invaluable assistance and are too numerous to thank individually. My gratitude is offered to the participants of CALL 2013 for their encouragement and helpful suggestions. I would like to acknowledge significant input from Maarten Mous, Doris Payne and Jeff Good, each of whom helped to guide this paper in a good direction through their numerous comments on early drafts. Finally, heartfelt thanks to the editors and anonymous reviewers for their helpful suggestions. Any errors are accepted as the responsibility of the author.

2 "Tracking participants" refers to the means by which participants or characters in a text are referred to throughout the various stages of the text. This includes participant introduction (activation), second mention, reactivation, etc. See Levinsohn (2014) and Dooley and Levinsohn (2001) for more details. 
demonstratives encoding referential information of a more abstract nature, such as "emotional attitude, or personal interest, or familiarity". Although observations of the subjective use of demonstratives are offered in some of the literature, such features appear to be unaccounted for in other classificatory and typological treatments of demonstratives (cf. Diessel 1999; Himmelmann 1996). Therefore, following illustration of various uses of the Ncane anaphoric demonstratives, I will conclude with some thoughts regarding the expansion of typological categories to account for such subjective uses.

The term demonstrative in this article refers to that set of nominal modifiers which primarily expresses some deictic relationship between a referent and the speaker. Ncane has two major types of demonstratives: spatial demonstratives and anaphoric demonstratives. Each is treated in turn in the following sections. But before we turn our attention to demonstratives, it will be good to give a brief presentation of the Ncane noun class system.

Ncane exhibits at least fifteen noun classes, which are summarized in Table 1. Noun class designations in this article are informed by Hombert (1980), and largely correspond to the numbering system established by early Bantuists (Maho 1999:51). The main exception is class 27, which appears to be Hombert's creation. ${ }^{3}$ Most of the noun classes utilize nominal prefixes, with classes 1, 3, 4, 5, 9 and 10 being exceptions: classes 1, 4 and 5 have no class marking at all; class 3 nouns are indicated by labialization of the initial consonant of the root; and classes 9 and 10 follow the same pattern as most other Beboid languages, being differentiated by tone only.

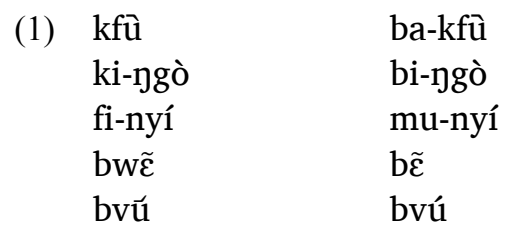

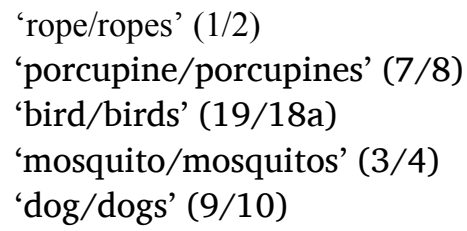

Nouns are grouped into classes based primarily on their agreement patterns with associated words in a sentence. Most word classes that modify the noun must show agreement, or concord, corresponding to the noun that is modified. This includes demonstratives, numbers, quantifiers and possessive pronouns. Other word classes showing concord are subject and object pronouns, relative pronouns and associative markers joining nouns in associative noun constructions.

Concord markers most often have a CV shape, with the concord consonant generally consistent regardless of the word class involved. However, an alternate form is observed in classes 3, 4, 6 and 10, when affixed to certain demonstratives. For example, concord for class 3 is $w u$ - when affixing quantifiers and possessive pronouns, but $k f u$ - when affixing spatial demonstratives. Therefore, the concord of demonstratives is sometimes the sole difference

3 The presence of at least two locative classes has also been observed with the prefixes $f \varepsilon$ - and $a$-, corresponding to classes 16 and 18. These classes have yet to be studied in detail and thus are not addressed here. See Hyman (1981) for a description of these classes as observed in the neighboring language Noni. Class 6a, which includes non-count nouns and which is prevalent among neighboring languages, is extremely rare in the data. Common class 6a members like 'blood' and 'water' are found in classes 7 and 9 . Because of the small numbers of class $6 a$, it is not included in this analysis. 
between the agreement patterns of two noun classes, thus establishing the two groups of nouns as distinct classes, as illustrated in (2) below.

$\begin{array}{lll}\text { (2) nà } & \text { wú-mu } & \text { 'a certain cow' } \\ \text { 1.cow } & \text { 1-certain } & \\ \text { gwí } & \text { wú-mu } & \text { 'a certain net' } \\ \text { 3.net } & \text { 3-certain } & \\ \text { nà } & \text { wú-ne } & \text { 'this cow' } \\ \text { 1.cow } & \text { 1-this } & \\ \text { gwí } & \mathbf{k f u ́} \text {-ne } & \text { 'this net' } \\ \text { 3.net } & \text { 3-this } & \end{array}$

The noun classes are organized in Table 1 according to their primary singular-plural pairings. Note that classes 3 and 5 belong to two singular-plural pairings each. Thus, we have genders $3 / 4$, $3 / 27,5 / 6$ and 5/27. Only the concord consonants are given, since concord vowels, when present, are sometimes variable. Mid tone has been marked where appropriate to differentiate mid-toned markers from those with no associated tone (i.e., nominal markers for classes 1, 3, 4 and 5). ${ }^{4}$

\begin{tabular}{|c|c|c|c|c|c|}
\hline \multicolumn{3}{|c|}{ Singular } & \multicolumn{3}{|c|}{ Plural } \\
\hline $\begin{array}{l}\text { Class } \\
\#\end{array}$ & $\begin{array}{l}\text { Nominal } \\
\text { marking }\end{array}$ & $\begin{array}{l}\text { Concord } \\
\text { marking }\end{array}$ & $\begin{array}{l}\text { Class } \\
\#\end{array}$ & $\begin{array}{l}\text { Nominal } \\
\text { marking }\end{array}$ & $\begin{array}{l}\text { Concord } \\
\text { marking }\end{array}$ \\
\hline 1 & $\varnothing$ & $w^{\prime}$ & 2 & bā- & $b^{-}$ \\
\hline 3 & $-\mathrm{w}_{-}$ & $\mathrm{w}^{-} / \mathrm{kf}^{-}$ & 4 & $\varnothing-$ & $\mathrm{y}^{-} / \mathrm{ch}^{-}$ \\
\hline \multirow[t]{2}{*}{5} & $\varnothing-$ & $\mathrm{ch}^{-}$ & 6 & $\overline{\mathrm{a}}-$ & $\overline{\mathrm{a}} / \mathrm{k}^{-}$ \\
\hline & & & 27 & chī- & $\mathrm{ch}^{-}$ \\
\hline 7 & kī- & $\mathrm{k}^{-}$ & 8 & bì- & $b^{-}$ \\
\hline 9 & $\because$ & $y^{\prime}$ & 10 & '- & $\mathrm{y}^{-} / \mathrm{ch}^{-}$ \\
\hline 14 & $\mathrm{~b}(\mathrm{v}) \overline{\mathrm{u}}-$ & $\mathrm{b}(\mathrm{v})^{-}$ & 25 & māN- & $\mathrm{m}^{-}$ \\
\hline 19 & fì- & $\mathrm{f}^{-}$ & $18 \mathrm{a}$ & mù(N)- & $\mathrm{m}^{-}$ \\
\hline
\end{tabular}

Table 1. Ncane noun classes

\section{Spatial Demonstratives}

Ncane exhibits a bipartite system of spatial demonstratives which identify the referent in terms of relative distance from the deictic center, which is most commonly the speaker. The proximal demonstrative ne marks referents located near the speaker. The distal demonstrative ge marks referents located far from the speaker. These two demonstratives combine with a set of noun

4 For a more detailed presentation, see Boutwell (2010). 
class concord prefixes and normally immediately follow the noun in the noun phrase. Example (3) illustrates the distance contrast expressed by these demonstratives and could be uttered when the speaker is holding a cutlass and the addressee is holding a different cutlass.
(3) Jó nyo yi-ne, nyo yì-gè kəde gè. take 9.cutlass 9-this 9.cutlass 9-that sharp NEG
'Take this cutlass, that cutlass is not sharp.'

Table 2 gives the full set of spatial demonstratives.

\begin{tabular}{llllll}
\hline & Proximal & Distal & & Proximal & Distal \\
\hline 1 & wúne & wùgè & 2 & báne & bagà \\
3 & kfúne & kfùge & 4 & chéne & chege \\
5 & chéne & chègè & 6 & káne & kàgà \\
& & & 27 & chéne & chègè \\
7 & kíne & kìgè & 8 & bíne & bìgè \\
9 & yíne & yige & 10 & chéne & chege \\
14 & búne & bùgè & 25 & máne & màgè \\
19 & fíne & fige & $18 \mathrm{a}$ & múne & mùngè \\
\hline
\end{tabular}

Table 2. Ncane spatial demonstratives

Rarely, the proximal demonstrative may precede the participant being referenced. This change in order results in greater prominence or emphasis of the participant. This can be seen in example (4) below.
(4) Lé, "Wú-nè kwèse wu nyùme nyày wù ká nyumè COMP 1-this 1.woman 1REL become 9.animal 1REL ITER become

mù wu wùn, lé kwèse wu nèc lè?”
1.person 1AM 1.world COP 1.woman 1REL how COMPL
'(He said), "This woman who is an animal and again a human, what kind of woman is she?",

Anaphoric reference is made when the demonstrative is coreferential with a participant mentioned earlier in the discourse. Example (5) illustrates the use of the proximal demonstrative for this type of reference. The text "The Ncane Land Dispute" is about a neighboring people group trespassing into Ncane territory. The referent "boundary" is mentioned early in the text, with the sentence in example (5) coming five sentences later. 


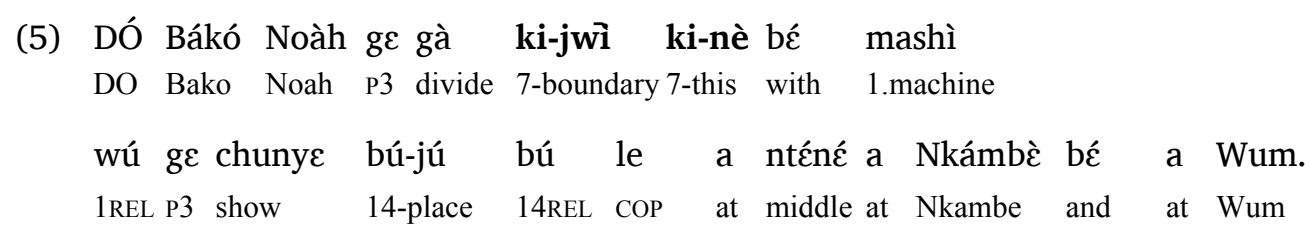

'DO (Divisional Officer) Bako Noah ${ }^{5}$ made this boundary by using a machine (telescope) which indicated a place midway between Nkambe and Wum.'

Because 'boundary' is mentioned earlier in the text, the reference in this example may be described as anaphoric. In the data corpus, the distal demonstrative is never observed to be used for this purpose while the proximal demonstrative is only rarely used in this way. It is unclear at this time how the use of the spatial demonstratives in anaphoric reference differs pragmatically from that of the anaphoric demonstratives, which are described in section 3 below.

\section{Anaphoric Demonstratives}

Anaphoric demonstratives are defined by Diessel (1999:6) as those which are "coreferential with a noun phrase in the preceding discourse;" that is, they point to or demonstrate a referent that has been previously mentioned. Ncane makes use of two such demonstratives, which I refer to as Anaphoric 1 (ANA1) and Anaphoric 2 (ANA2), with the stems $\grave{\varepsilon}$ and $y u$ respectively, and which, like the spatial demonstratives, take a noun class concord prefix corresponding to the noun they modify. The full set of anaphoric demonstratives is given in Table 3.

\begin{tabular}{|c|c|c|c|c|c|}
\hline & ANA1 & ANA2 & & ANA1 & ANA2 \\
\hline 1 & Wعغ̀ & wúyú & 2 & baà & báyú \\
\hline 3 & kwêे & wúyú & 4 & chદદ̀ & yíyú \\
\hline \multirow[t]{2}{*}{5} & chič & chíyú & 6 & kaà & áyú \\
\hline & & & 27 & chic̀ & chíyú \\
\hline 7 & kè̀ & kíyú & 8 & biè & bíyú \\
\hline 9 & 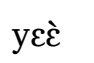 & yíyú & 10 & chič & yíyú \\
\hline 14 & bwê & búyú & 25 & maà & máyú \\
\hline 19 & fiè & fíyú & $18 \mathrm{a}$ & mwê & múyú \\
\hline
\end{tabular}

Table 3. Ncane anaphoric demonstratives

Note that anaphoric demonstratives with similar forms have been identified in some neighboring languages. Noni can make anaphoric reference through the use of the "near hearer" demonstrative, which has the stem $\varepsilon$ or $a$. A second demonstrative, which apparently is used strictly for anaphoric reference, has the stem $d v u$. Although both of these demonstratives are

5 This is a pseudonym. 
possibly cognates of Ncane ANA1 and ANA2 respectively, no evidence is offered demonstrating that they function beyond making anaphoric reference (Hyman 1981:24).

Cognates are also identifiable in Mungong, currently classified as a Ncane variety. Closely following the Noni demonstrative pattern, Mungong makes anaphoric reference through the distal (non-far) demonstrative, which has $i, \varepsilon$, $i$, or $i \eta$ as the stem, depending on the noun class of the referent. A second demonstrative, apparently dedicated to anaphoric reference, has the stem juy (Boutwell 2014:10). Again, no evidence is provided to show any function other than anaphoric reference.

A detailed description of demonstratives in the Beboid language Naki appears to be lacking at this time. However, data from a manuscript describing the Naki noun class system presents proximal and distal paradigms, as well as a third demonstrative that possibly makes anaphoric reference. The stem vowel of this third demonstrative is a or $\varepsilon$ (Good 2010a), apparently cognate with the Ncane ANA1. Examples from a Naki text also show the class 10 proximal demonstrative $y \bar{\varepsilon} n \grave{i}$ used in making anaphoric reference (Good 2010b:44).

The Ncane anaphoric demonstratives usually accompany major participants ${ }^{6}$ at second mention, after which participants are normally referred to through the use of pronouns, unless disambiguation is required. Example (6) illustrates the common pattern of anaphoric demonstrative use in Ncane. The referent "teeth" is introduced in the first sentence with a bare noun. Reference to "teeth" in the second sentence is accompanied by the anaphoric demonstrative biغ̀.

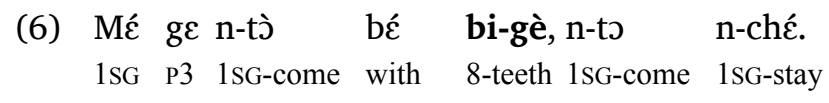

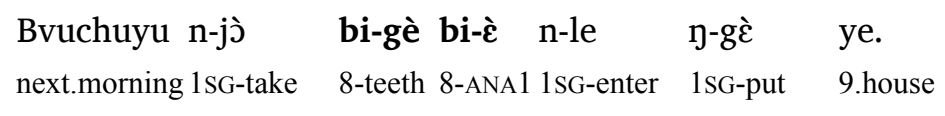

'I brought some money (lit. teeth) and slept. The next morning, I took that money and put it in my house.'

Reactivation of participants normally occurs at discourse episode boundaries via use of a full noun phrase plus an accompanying anaphoric demonstrative. ${ }^{7}$

Along with serving to track participants, these anaphoric demonstratives are often used to encode some kind of evaluation of the referent by the speaker. This evaluation can usually be characterized as either negative in nature or neutral, with the Anaphoric 2 demonstrative expressing a negative evaluation and the Anaphoric 1 expressing a neutral evaluation. Speakers appear to be generally quite conscious of the demonstratives' use in negative expression, although in certain contexts the choice of demonstrative appears to be debatable and highly context dependent. The range of senses of negative expression possible in language is quite

6 The notion of "major participant" here follows that outlined by Dooley and Levinsohn (2001:60), referring to participants which are "active for a large part of the narrative and play leading roles."

7 Proper nouns and possessed nouns are observed to occur without any anaphoric demonstrative. 
broad. The examples in the remainder of this section will illustrate some of the semantic variation observed.

As mentioned above, the Anaphoric 2 demonstrative is often used to express something of a negative evaluation of the referent. This can be interpreted as an emotional judgment by the speaker regarding the wholeness, appropriateness, dangerousness or evil associated with the referent. For instance, the Anaphoric 2 demonstrative is often used to indicate the occurrence or potential occurrence of a surprising event. However, it usually implies that the event has a potentially dangerous or otherwise undesirable consequence. Example (7) is the only occurrence of ANA2 in the text "When You Do Good, You Do for Yourself". A woman has poisoned some food to be given to a persistent and troublesome beggar. Surprisingly, her own children end up eating the poisoned food and their father is called to come and see the "thing" that is happening.

$\begin{array}{lllllllllll}\text { (7) Wú to } & \text { wú } & \text { yen } & \text { fi-è } & \text { fi-yú } & \text { nyu } & \text { a } & \text { je } & \text { yí-mi } & \text { le. } \\ \text { 3SG } & \text { come } & \text { 3SG } & \text { see } & \text { 19-thing } & \text { 19-ANA2 } & \text { being } & \text { at } & \text { 9.road } & \text { 9-certain } & \text { COMPL }\end{array}$

'He came and saw that thing was in a deteriorating condition.'

The "thing" that has happened, refers to the children having eaten poison, which is judged as a negative event and thus is marked with ANA2. Additionally, this occurrence of ANA2 is at the point of greatest climactic tension in the narrative.

ANA2 can be used to emphasize a contrast between two or more participants. This is illustrated in example (8), taken from a text about a man with two wives. The major participants are presented in the setting ${ }^{8}$ of the story, where we learn that one of the wives is a witch. The story develops with the two wives planting corn in a field. The "normal" wife realizes that someone or something is eating her corn. She decides to hide in the bushes to see who or what is responsible. As she is hiding, she sees a woman arrive who resembles her fellow-wife. This woman is carrying a food mat in her hand, which she rubs on her body. This action changes her into an animal. The animal then begins to eat the corn, wandering away in the process.

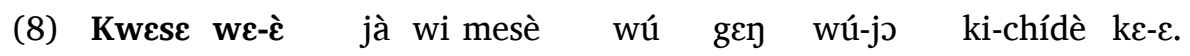

1.woman 1-ANA1 rise up complete 3SG go 3SG-take 7-food.mat 7-ANA1

Wú légè wú kwè bé ki.

$3 \mathrm{SG}$ run $3 \mathrm{SG}$ home with $7 \mathrm{PRO}$

Kwesé wu-yú shè nchùy à nyày le.

1.woman 1-ANA2 stay bush to 9.animal COMPL

'The woman got up, went and took that food mat. She ran home with it. That (other)

"woman" remained in the bush as an animal.'

Prior to this event, references to these two women include relative clauses to disambiguate them. Use of relative clauses is particularly evident during this episode, since both women are

8 "Setting" is what Longacre (1996:34) refers to as "exposition", and relates to crucial information such as time, place, etc. 
active participants at the same time. However, the use of ANA1 is sufficient here to let us know that it is the "normal" wife who picks up the food-mat and runs home, and ANA2 is sufficient to let us know that the "witch-wife" is the woman who remains as an animal in the bush. The contrast between the "normal" wife and the "abnormal" wife emphasizes the negative state of the woman-animal - a woman who has changed into an animal is not normal, and possibly considered dangerous as well.

Sometimes, the presence of ANA2 expresses a foreboding - something surprising and bad is going to happen related to the participant. In example (9), three friends have bought a cow for the purpose of slaughtering it and selling the meat for a profit. One of the friends suggests that when they slaughter the cow, they should lay it on top of him so that nothing from the cow is wasted. ${ }^{9}$

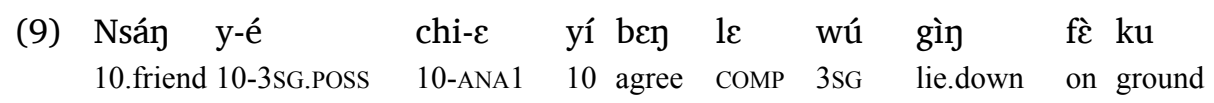

$\begin{array}{llllllll}\text { bó } & \text { kó } & \text { nà } & \text { wu-yú } & \text { bo tun } & \text { wu } & \text { lé } & \text { wè. } \\ 3 \text { PL } & \text { catch } & 1 . \text { cow } & 1-A N A 2 & 3 P L \text { throw } & 3 S G & \text { COMPL } & \text { up }\end{array}$

'The friends agreed that he should sleep on the ground so they could lay that cow on him.'

Throughout the previous sentences of this episode, references to the cow are made with ANA1. Now, however, the cow is referred to with ANA2, giving the hearer a sense that something wrong is going to happen. And indeed, when the friends lay the cow on the man, he is pierced by the horn of the cow and dies.

Similarly, a kind of flashback ${ }^{10}$ function can be seen in example (10). This example is found at an episode boundary, with the previous episode presenting a crisis event, where people are crossing a lake during a violent storm. The people survive the storm and reach the other shore. Although the danger has passed, the lake is referred to using ANA2. This reference evokes the emotions associated with the previous event, where the storm threatened to drown all those aboard the small boat. ${ }^{11}$

9 Presumably, laying the cow on the ground would cause part of the cow to become dirty and result in those dirty portions being unusable.

10 The use of the term "flashback" here is intended only to highlight the evocation of emotion associated with a previous event.

11 While this example comes from translated material, native speakers readily accept it as natural. Furthermore, the original source text does not contain any similar flashback devices. Because "the lake" played a major role in the previous episode, the language demands the use of an anaphoric demonstrative with this reference. The use of ANA1 here would seem to ignore the very important role "the lake" played in the life-threatening previous episode. 
(10) Bó dày mámásí wú-yú
3PL cross
1.lake

$\begin{array}{llllllll}\text { bó } & \text { bú } & \text { wôy } & \text { kwé-gê } & \text { ki-mbè } & \text { ki } & \text { Gélasèn } & \text { lè. } \\ \text { 3PL } & \text { exit } & \text { 3.country } & \text { 3-that } & \text { 7-side } & \text { 7AM } & \text { Gerasenes } & \text { COMPL }\end{array}$

'They crossed that lake and arrived at the region of Gerasenes.'

The extreme, subjective nature of this demonstrative's use is illustrated in example (11), which comes from a hortatory text giving advice on marriage. The sentence prior to this one states that a mature boy and mature girl (i.e., "the children") will agree to stay together as one, to be like man and wife.

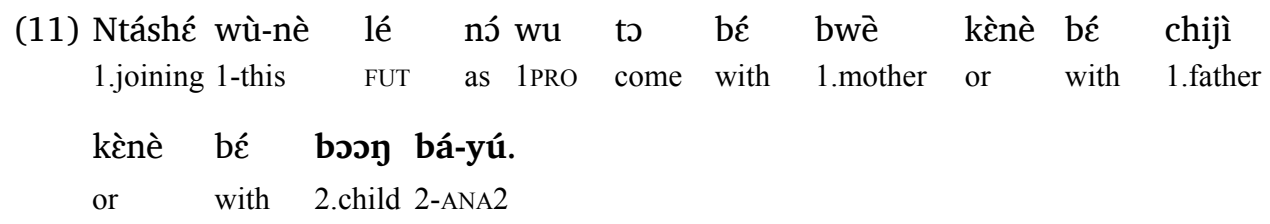

'This joining (or agreement to join) will come from the mother, the father or those children.'

On the surface, the reason for the choice to use ANA2 with "children" is not transparent. Nothing bad happens later in the text. Nor are the children obviously considered evil or abnormal. This was pointed out to me by native speakers when I asked about the reason for the occurrence of ANA2 here. The native speakers consulted then began to discuss the possibility that the presence of ANA2 here is simply a mistaken utterance.

The choice to use ANA2 becomes clear, however, when we consider the social context. Historically, Ncane marriages were arranged with a high degree of involvement of both families, particularly the mothers and fathers of the bride and groom. However, it is reported that, with increasing frequency, young men and women are bypassing the cultural norms of marriage by making the arrangements without parental involvement. The speaker of this text is an older man and a religious leader in the community. It is likely that he has a traditional view of marriage. By using ANA2 with "children", he is subtly stating that he believes it is bad for children to make marriage arrangements without their parents being involved. After initially discussing the possibility that it was a faulty use of the demonstrative, the native speakers consulted agreed with this conclusion. But there are likely many people who would disagree with the speaker's attitude. So, if they were to give the same discourse, they might choose ANA1 to use with "children", expressing no negative judgment of such a departure from tradition.

We have been looking at examples where ANA2 is used in adverse expression. However, there are occurrences of ANA2 that do not coincide with negatively viewed referents, at least not clearly so. The notions of totality and inherent complexity, for example, are sometimes observed to be accomplished through ANA2. Likewise, there appears to be a preference for ANA2 for certain abstract referents. The following examples illustrate some of these kinds of expression.

The use of ANA2 in example (12) appears to express the quality of intensity. In the text the speaker recounts a training program he attended which resulted in him winning a flight in a 
helicopter. He certainly considered this a positive experience. However, he wants to indicate that "the meeting" was serious in content and that the training was rigorous.

(12) Bá-mí ge sisè nshilè wu je yi Nyj̀.

2-person $\mathrm{P} 3$ decide 1.meeting 1AM 9.word 9AM God

\begin{tabular}{|c|c|c|c|c|c|c|}
\hline Nshìlè & wu-yú & gè bé & kone & bá-mî & bá-nfíje & yi \\
\hline 1.meeting & 1-ANA2 & P3 P.COP & about & 2-person & 2-preaching & 9.word 9AM \\
\hline
\end{tabular}

'People organized a Bible meeting. This meeting was for training preachers.'

In addition to intensity, ANA2 here might also express something about the depth characterizing the meeting. From the larger context it is clear that this meeting had several elements of training, possibly even multiple sessions running at one time over a number of days. This is in contrast to a "simple" meeting with one topic, one presenter and only one session. One might interpret this expression of broadness and intensity as "complexity". The native speaker from whom this text was elicited could not easily explain his reason for choosing to use ANA2 here. He also suggested that using a different demonstrative would be equally correct. But he agreed that its use could be interpreted as an indication of the complexity and difficult nature of the training.

Sometimes, it is not clear that a single reason motivates choice of ANA2 because there are various senses or uses of ANA2, and therefore, several possible reasons could simultaneously motivate its use in a given discourse. The following example is from an historical text about a land dispute.

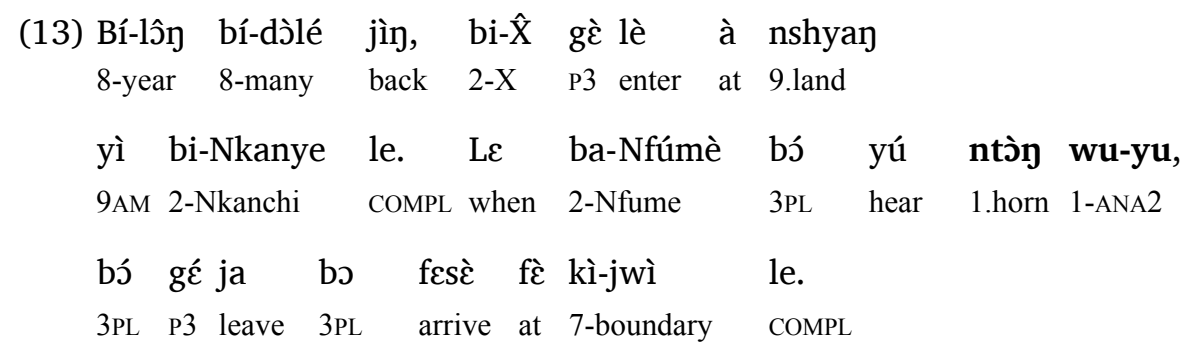

'Some years back, the $\mathrm{X}^{12}$ people trespassed into Nkanchi territory. When the people of Nfume heard that news (lit. that horn), they left for the disputed area.'

The reason for the use of ANA2 here is somewhat ambiguous. Like example (7) above, the news of their land being trespassed upon is judged as a negative event. Therefore, we expect that ANA2 should be used in referring to the news of the event. In addition, however, a corpus search suggests that any referent that is "heard" is preferentially marked with ANA2, a notion supported by a number of native speakers when posed the question. Therefore, "hearing that horn" would normally be marked with ANA2, regardless of the desirability of the news.

12 The name of this people group has been obscured as to avoid offense. 
Example (14) is a second example from the story about the man with two wives and is another case where the use of ANA2 is somewhat ambiguous.

(14) Bi-kesé ba-a

2-women 2-ANA1 gè kem-è mwén wu

P3 have-IPFV 3.farm 3AM bô, lé wú as $3 \mathrm{PRO}$ one

$\begin{array}{llllllll}\text { Bó } & \text { ge bòn } & \text { bi-nfune } & \text { yú, } & \text { bi-nfune bi-yú } & \text { joy } & \text { wesè. } \\ \text { 3PL } & \text { P3 plant } & \text { 8-corn } & \text { in } & \text { 8-corn } & \text { 8-ANA2 } & \text { good } & \text { very }\end{array}$

'Those women had one farm. They planted corn and that corn (grew) very well.'

In this example, the two wives have divided a field in half, each working her own half and both planting corn. Later in the story, the second wife's corn is being eaten by the first wife after she had transformed herself into an animal. Therefore, ANA2 might be used here to communicate a foreboding. In other words, something surprising and bad is going to happen involving the corn.

However, this reference appears to also indicate that both halves of the field are included in the reference, not just one half. A consulted native speaker suggested that, if ANA1 was used in place of ANA2, a potential interpretation is that the reference is to only one of the women's corn. Therefore, one of the two halves of the field of corn would NOT be growing well. Furthermore, he pointed out that the implication would be that the witch-wife is somehow sabotaging the corn of the other wife to keep it from growing well. While we learn later that the witch-wife is indeed doing something to the second wife's corn, at this point in the story, the fact is that both women's corn is growing well.

The above examples illustrate the variety of kinds of expression the Anaphoric 2 demonstrative is observed making. These are summarized in the following list.

- Negative counter-expectation

- Negative contrast

- Negative foreboding

- Negative flashback

- Negative speaker comment

- Inherent complexity

- Abstract quality

\section{Discussion}

Ncane offers multiple options for anaphoric reference. While the proximal demonstrative may be used for this function, most of the time the anaphoric demonstratives are used. ANA1 usually makes no evaluative statement concerning the referent, while ANA2 often expresses a negative evaluation of the referent. Pragmatically, a speaker can choose to use ANA1 with most referents, while ANA2 is more limited as a choice.

Diessel (2012:2418-9) states that the semantic features of demonstratives can be divided into two types-deictic, locating the referent relative to the deictic center, and non-deictic, characterizing the type of referent. And demonstratives "are usually organized in paradigms of contrastive forms." This suggests that demonstratives normally are not interchangeable and 
choice among them is governed by their basic meanings. For example, the Ncane proximal demonstrative cannot be used with referents that are far away and the distal demonstrative cannot be used with referents that are near. In a similar way, ANA2 usually cannot be used with just any referent. The referent must normally be judged by the speaker to possess some negative or difficult quality or to be associated with such a quality.

Admittedly, the semantic domain of "adversativity" is broad with many nuances of meaning. As illustrated above, ANA2 can be used to comment on negatively viewed events. The event can be set in the past, present or future. Additionally, the referent's association with the negative event can be somewhat peripheral in nature, as illustrated by example (14). The "negative event" in this case is the eating of the normal wife's corn by the witch-wife. There is nothing intrinsically negative about the corn, which is simply a prop in the story.

Another example of this "peripheral association" is illustrated in a story about a tribe of rats which is being terrorized by a cat. The rats devise a plan to tie a bell onto the cat's tail so that when the cat comes, they will hear the bell and run away.

\begin{tabular}{|c|c|c|c|c|c|c|c|c|}
\hline (15) “Lé yع̄ & wu le & wu & shu & mbìar & & yع-غ̀ & yè Đvū & $\mathrm{wu}$ \\
\hline COPwho & 1REL & $3 \mathrm{SG}$ & tie & 9.bell & & 9-ANA1 & on 3.tail & $3 \mathrm{AM}$ \\
\hline mbùsha & le." & $\mathrm{b} \varepsilon \eta$ & $1 \varepsilon$ & lé & ki & & & \\
\hline 1.cat & COMPL 3PL & agree & COMP & $\mathrm{COP}$ & $7 \mathrm{PR}$ & & & \\
\hline ki-kfunè & kí-kùge & ki-yídè & $\mathrm{k} \varepsilon-\varepsilon$ & kí & lé & kí shú & mbìan & \\
\hline 7-rat & 7-big & 7-black & 7-ANA & 1 7REL & FUT & tie & 9.bell & \\
\hline
\end{tabular}

"“Who will tie the bell on the cat's tail?" They agreed that it would be the fat, black rat who would tie that bell.'

In the next sentence, the cat arrives and begins to chase and catch the rats, which is obviously a negative event. However, the "bell" is only very loosely associated with the event of the cat's arrival, being only hypothetical at that time.

ANA2 is also used with referents that are judged to be somehow faulty or abnormal, as illustrated by the witch-wife in example (8). This expression of defectiveness can sometimes be seen with human referents who are ill, handicapped in some way or mentally deranged. Also marked with ANA2 are dangerous things - cows that kill, for example. Storms are preferentially marked with ANA2. And we saw in example (10) where a referent simply associated with a storm was marked with ANA2.

In example (11) I showed how ANA2 can be used to express disdain for a certain kind of behavior, that of children not following traditional marriage customs. This certainly illustrates the subjective nature of ANA2. Presumably, all speaker judgments are subjective, even though shared worldview largely dictates shared assumptions regarding "good" and "bad". The important thing for the purposes of this paper is to recognize that, regardless of the hearer's own judgment, ANA2 is generally interpreted as expressing negative judgment of the referent by the speaker, thus evoking an appropriate emotional reaction from hearers.

Arriving at an accurate analysis of such a subjective phenomenon is fraught with difficulty and raises the question of alternative and competing analyses. While this paper focuses on 
pragmatics and semantic expression, it is clear that ANA2 also functions in ways that have more to do with syntax and discourse structure. These functions are not well understood at this time. But one such function certainly is that of increasing referent prominence or referent highlighting.

Prominence marking plays an important role at the level of discourse structure and story development. For example, ANA2 sometimes is not used with a major participant until an important turning point in the story or episode. This is observed in the story from which example (9) is taken, which is repeated below along with its discourse context. As a reminder, three friends buy a cow, only to have it kill one of them.

(16) Ba-mi ba-mu ba-tede.

2-person 2-certain 2-three

Bó gè bé nsay.

3PL P3 P.COP 10.friend

Bj́ sisc̀ ki bo gu nà bó sé bo gesè.

3PL decide INF 3PL buy 1.cow 3PL slaughter 3PL sell

$\mathrm{L} \varepsilon$ bó gu na we-è bo to bé wù, mu wu-mù

after 3PL buy 1.cow 1-ANA1 3PL come with 1PRO 1.person 1-certain

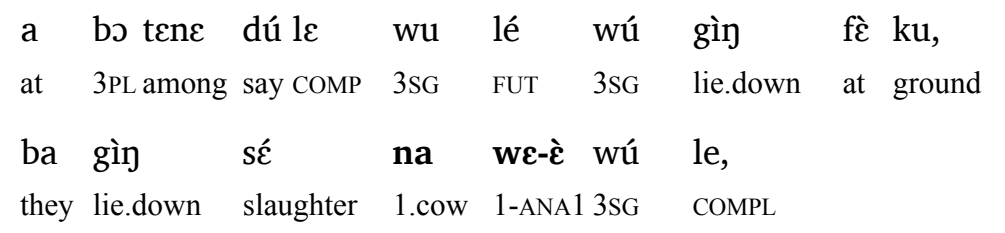

nje bo gòné le $\quad k \varepsilon \quad$ fyé $\quad$ fí-mí lesè gè.

reason 3PLwant COMP NEG 19.thing 19-some lose NEG

Nsán y-é chi-e yí bey le wú gìn fè ku

10.friend 10-3SG.POSS 10-ANA1 10 PRO agree COMP $3 \mathrm{SG}$ lie.down on ground

bó kó nà wu-yú bo tụ wu lé wè.

3PL catch 1.cow 1-ANA2 3PL throw 3SG COMPL up

Le bó tụ na wú le ki-ncho ki nà mò ki bọ wù

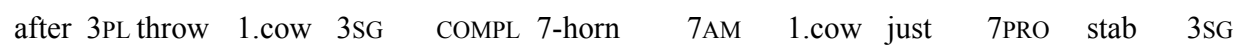

wu kwe.

$3 \mathrm{sg}$ die

'There were three men. They were friends. They arranged to buy a cow to slaughter and sell. When they bought the cow and brought it, one of them said he would sleep on the ground, then the cow would be placed on him, because they don't want anything to be wasted. The friends agreed that he should sleep on the ground so they could lay that cow on him. When they caught the cow and threw it on him, the cow's horn pierced him and he died.' 
The referent "cow", when it has argument status, receives full nominal reference five times during this episode. At the first mention, the bare noun is used. At the second and third mentions, the referent occurs with ANA1, marking this participant as an important one in the episode. The fourth mention occurs with ANA2 at the point of greatest tension in the episode, and the only time the reference occurs with ANA2 in the entire text. The use of ANA2 at this time, serves to raise the attention of the hearers and prepare them for the unexpected event of the friend being killed by the cow. Note also the full nominal reference for "friends", including a possessive pronoun and ANA1, all of which contribute to the tension at this point in the episode. The fifth mention occurs with just the bare noun during the conclusion of the episode, when the cow's horn actually pierces the friend and kills him.

We see, therefore, that the choice of which demonstrative to use is not always simply based on speaker attitude, but is also a reflection of story-telling technique and discourse related function. Indeed, some of the texts in the corpus contain no occurrences of ANA2 at all, suggesting that the stories are not well-crafted, or that the speakers did not desire to be overly "dramatic". In other texts, it appears that the speaker chooses which participants should be marked as prominent and which should not. This sometimes results in ANA2-marked participants that are arguably less adversive in nature compared to unmarked participants in the same text. In other words, the anaphoric demonstratives sometimes function primarily as prominence-marking devices rather than expressing adversativity.

However, some referents appear to almost always take ANA2, suggesting that grammaticalization is in process. As mentioned above, storms are considered dangerous and almost always are marked with ANA2, although they can occur with ANA1 once the storm has passed and the danger presumably over. Sounds are also almost always marked by ANA2. Likewise, dreams and ghosts are usually marked with ANA2, irrespective of their status or location within the story. Each of these referents can be viewed as relatively abstract in nature. Clearly some of these kinds of referents are identified with some particular semantic domain underlying the choice of ANA2, such as a connection to the spirit world. ${ }^{13}$

Admittedly, throughout the text corpus, ANA2 appears to be most often used with participants that are relatively less animate on the animacy scale. However, there are examples of ANA1 marked inanimate objects appearing in the same text with ANA2 marked humans. Thus, in these cases at least, an analysis other than animacy is required. Along with prominence marking, native speaker intuition appears to support the conclusion that some kind of negative expression is typically inherent to the semantics of ANA2.

As noted above, Diessel (1999) describes the semantics of demonstratives as comprising two kinds of features: deictic and qualitative. The deictic feature has to do with locating the referent relative to the deictic center. Qualitative features, he states, are those "which characterize the referent." He divides qualitative features into the following six categories: ontology differentiating between location and person or object; animacy - differentiating between animate and inanimate; humanness - human versus nonhuman; sex - female or male; number differentiating between singular and plural, etc.; and boundedness - differentiating between referents that can be completely seen and those that cannot.

13 See Blust 2001, for an example of language grammaticalizing spiritual attachment. 
While this typology would seem to allow for speaker evaluation of qualities such as animacy and humanness (i.e., physical qualities and therefore open to objective measurement), it does not include evaluation of a more subjective nature such as a perceived association with danger or negativity. The expression of negative evaluation, a seemingly core semantic element of the Anaphoric 2 demonstrative, does not seem to fit very well in either Diessel's "deictic" or "qualitative" categories. I suggest that a third category of semantic feature would be useful to amplify the typology, perhaps designated as "emotive".

Indeed, the literature does offer examples of emotional expression through demonstrative use in other languages. For example, Meeuwis and Stroeken (2012) observe a pejorative use of anaphoric demonstratives in Lingala. Insult and praise can be expressed through the use of demonstratives in some Gur languages, as noted by Lébikaza (2005). Varying degrees of irritation are expressed through demonstratives in Bafut, a nearby Grassfields language (Mfonyam 2012). Demonstratives in Tamil can be used to generate emotional proximity, a function described as "subjective deixis" (Herring 1994). And Lakoff (1974) provides examples from English, referring to "emotional deixis"- the use of spatial demonstratives to express a sense of solidarity, vividness or sympathy.

The main goal of this article has been to present novel data pertaining to anaphoric demonstratives in Ncane. However, the data also bear on the typology of demonstratives. I have demonstrated that the notion of adversativity, with various nuances, appears to be intrinsic to the semantics of one pair of the Ncane demonstratives. As the broader literature demonstrates, Ncane is not unique in this regard.

\section{Abbreviations}

\begin{tabular}{|l|l|l|l|}
\hline 1 & noun class 1 & COP & copula \\
\hline 2 & noun class 2 & FUT & future \\
\hline 3 & noun class 3 & INDEF & indefinite \\
\hline & etc. & INF & infinitive \\
\hline 1SG & first person singular & IPFV & imperfective \\
\hline 3 SG & third person singular & ITER & iterative \\
\hline 3PL & third person plural & NEG & negative \\
\hline ANA1 & anaphoric 1 & P3 & remote past \\
\hline ANA2 & anaphoric 2 & P.COP & past copula \\
\hline AM & associative marker & POSS & possessive \\
\hline COMP & complement particle & PRO & pronoun \\
\hline COMPL & completive particle & REL & relative adjective \\
\hline
\end{tabular}




\section{References}

Blust, Robert A. 2001. "Historical Morphology and the Spirit World: *qali/Kali-Prefixes in Austronesian Languages." In Issues in Austronesian Morphology. A Festschrift for Byron W. Bender, edited by John Bradshaw and Kenneth L. Rehg, 15-73. Canberra: Pacific Linguistics.

Boutwell, Richard L. 2010. A Sketch Grammar of the Nchane Language. Yaoundé: SIL. http://www.silcam.org/languages/languagepage.php?languageid=208.

Boutwell, Richard L. 2014. A Sketch Grammar of the Mungong Language. Yaoundé: SIL. http://www.silcam.org/languages/languagepage.php?languageid=208.

Diessel, Holger. 1999. Demonstratives: Form, Function, and Grammaticalization. Amsterdam: John Benjamins.

Diessel, Holger. 2012. “Deixis and Demonstratives.” In Semantics: An International Handbook of Natural Language Meaning, edited by Claudia Maienborn, Klaus von Heusinger, and Paul Portner, 3:2407-31. Handbücher Zur Sprach- Und Kommunikationswissenschaft / Handbooks of Linguistics and Communication Science, 33.3. Berlin: De Gruyter Mouton.

Dixon, Robert MW. 2003. "Demonstratives: A Cross-Linguistic Typology." Studies in Language 27 (1): 61-112.

Dooley, Robert A., and Stephen H. Levinsohn. 2001. Analyzing Discourse: A Manual of Basic Concepts. Dallas: SIL International.

Good, Jeff. 2010a. "A Sketch of the Naki [Mff] Noun Class System.” University at Buffalo. http://www.acsu.buffalo.edu/ jcgood/jcgood-NakiNCs-draft.pdf.

Good, Jeff. 2010b. "Topic and Focus Fields in Naki." In The Expression of Information Structure: A Documentation of Its Diversity across Africa, edited by Ines Fiedler and Anne Schwarz, 91:35-67. Amsterdam: John Benjamins Publishing.

Herring, Susan C. 1994. "Discourse Functions of Demonstrative Deixis in Tamil." In Proceedings of the Twentieth Annual Meeting of the Berkeley Linguistics Society, edited by Suzanne Gahl, Andy Dolbey, and Chris Johnson, 20:246-59. Berkeley: Berkeley Linguistics Society.

Himmelmann, Nikolaus P. 1996. "Demonstratives in Narrative Discourse: A Taxonomy of Universal Uses.” In Studies in Anaphora, edited by Barbara Fox, 205-54. Amsterdam: John Benjamins.

Hombert, Jean-Marie. 1980. "Noun Classes of the Beboid Languages." In Noun Classes in the Grassfields Bantu Borderlands, edited by Larry M Hyman, 83-98. SCOPIL 8. Los Angeles, CA: Dept. of Linguistics, University of Southern California.

Hyman, Larry M. 1981. Noni Grammatical Structure. SCOPIL 9. Los Angeles, CA: Dept. of Linguistics, University of Southern California.

Lakoff, Robin. 1974. "Remarks on This and That." In Proceedings of the Tenth Regional Meeting of the Chicago Linguistics Society, edited by Michael W. LaGaly, Robert A. Fox, and Anthony Bruck, 10:345-56. Chicago: Chicago Linguistics Society.

Lébikaza, Kézié Koyenzi. 2005. "Deictic Categories in Particles and Demonstratives in Three Gur Languages.” In Studies in African Linguistic Typology, edited by F. K. Erhard Voeltz, 64:22949. Typological Studies in Language 64. Amsterdam: John Benjamins.

Levinsohn, Stephen H. 2014. "Self-Instruction Materials on Non-Narrative Discourse Analysis." Online at http://www.sil.org/ levinsohns.

Longacre, Robert E. 1996. The Grammar of Discourse. 2nd ed. New York: Plenum. 
Maho, Jouni. 1999. “A Comparative Study of Bantu Noun Classes.” PhD diss., Göteborg University.

Meeuwis, Michael, and Koenraad Stroeken. 2012. "Non-Situational Functions of Demonstrative Noun Phrases in Lingala (Bantu)." Pragmatics 22 (1): 147-66.

Mfonyam, Joseph Ngwa. 2012. "Repetition and Irritation Emphasis in Bafut." Journal of West African Languages XXXIX (1): 3-14.

Richards, Russell. 1991. "Phonologie de Trois Langues Béboïdes du Cameroun: Noone, Ncanti et Sali.” PhD diss., Paris 3.

Simons, Gary F., and Charles D. Fennig, eds. 2017. Ethnologue: Languages of the World. Twentieth edition. Dallas, Texas: SIL International. http://www.ethnologue.com.

Rich Boutwell

rich_boutwell@wycliffe.org
Submitted: 16 December 2014

Accepted: 31 May 2015

Revisions: 6 April 2018 